\title{
Final arrangements following Death: Maori Indigenous Decision Making and Tangi
}

\author{
Linda Waimarie Nikora
}

Bridgette Masters

Ngahuia Te Awekotuku

Maori \& Psychology Research Unit, University of Waikato, New Zealand

Contact email: psyc2046@waikato.ac.nz

Prepared for the Special issue on Case Study Research

Journal of Community and Applied Social Psychology

Submitted for review to the Journal of Community and Applied Social Psychology

Update 13 March 2012 


\section{Abstract}

Death is a universal event. It will happen to all of us, yet how we respond to death is particular and influenced by our cultural worlds. This study offers an investigation of the idiographic, of how one woman responded to, and made arrangements to, mourn and bury her mother. Specifically, we explore how she and her whanau (family) under pressure of time and grief and in the absence of clear final wishes, met to consider issues and make decisions about the situation they were confronted with. This case forms part of a much larger programme of research into Maori death rituals, change and adaption. Informing a scholarly audience unfamiliar with the Maori world requires a significant amount of contextual information. The case study is a powerful strategy to achieve this and one that draws readers into deep understanding (Willig, 2008). This case provides insight into the struggles of an indigenous fourth-world people living within the heterogeneity of Aotearoa/New Zealand society; it demonstrates how values change across generations as people live their lives increasingly away from their ancestral homelands; and how traditionally defined roles and responsibilities within the whanau (family) are challenged by members living away from each other. 


\section{Introduction}

Bereavement events occur in a larger context. Aotearoa/New Zealand is a culturally diverse society with Maori situated as an indigenous minority amongst the dominant Anglo-Celtic settler majority. Linguistically and culturally, Maori are closely related to peoples of Eastern Polynesia and settled in Aotearoa/New Zealand sometime around 800AD where they evolved a unique and adaptive culture (Te Awekotuku, Nikora, Rua, \& Karapu, 2007). Maori are tribal people with each tribe comprised of allied sub-tribal groups (hapu) that through genealogy and customary practices function to draw extensive networks of extended families (whanau) together as a political and caring community (Walker, 1992).

The cultural heart of hapu is the marae, a community meeting place, often with elaborately carved buildings that symbolize the identity of those whanau that constitute the hapu (Walker, 1992). As a functional environment, marae are usually comprised of a sleeping house (wharenui), dining room and kitchen (whare kai), and toilet and shower facilities. Most marae can sleep at least 100 people, and during the day serve to receive many more. Located not far from the marae is an associated cemetery (urupa) where ancestors have been interred. It is to these tribal lands and this culturally imbued environment and landscape, layered with spirit and memory, that Maori traditionally returned to mourn and inter their dead (Dansey, 1992).

Apart from work by Beaglehole and Beaglehole (1945, 1946), Metge (1976) and Salmond (1976) analysis of Maori death rituals (tangi) in previous literature remains informative rather than scholarly. Maori death practice is described and explained to concerned others, or to the health, religious or social welfare sectors, and 
mortuary industry. Tomas (2008) considers ownership of human remains, and Hera (1996) documents her interviews with older Māori women about tangi, and a perspective on Maori male responses to sudden infant death is offered by Edwards and colleagues (2009). While there is literature about customary values and practices in modern times (Barlow, 1991; Dansey, 1992; Harawira, 1997; Matenga-Kohu \& Roberts, 2006; Mead, 2003; Tauroa \& Tauroa, 1986), currently there is no definitive historical or contemporary published account of tangi and the Māori experience of death, which captures its fluidity, transformation and effect.

Tangi refers to a range of procedural mourning rituals, their beginning marked by the return of the deceased and the immediately bereaved to their marae. While this is the traditional pattern, some choose instead to mourn their family member in their own private homes, although it is more usual to combine mourning at both settings. It is understood that once the deceased arrives at the marae, the death must be shared with a broader grieving community, not just close family members. For Maori, the institution of tangi provides a customary way to respond to death. It is an enculturated pattern learned through repeat engagements beginning in childhood (Jacobs, Nikora, \& Ritchie, 2011 in press). At times of death, custom is a lifeline. It affords security, comfort and reassurance about what to do next and that the right thing will be done.

As we have described elsewhere (Nikora, et al., 2010), Maori mourning rituals can be enacted over a few hours or a few days. They include the rituals of encounter, lamentation and cathartic mourning, oratory, dirges, the recitation of genealogy, prayer and speeches of farewell. The proceedings are enhanced by the display of significant artefacts, like hand-woven textiles and jade weaponry that adorn the casket. Portraits of ancestors and deceased relatives are exhibited and the deceased is 
never left alone. They are conversed with as if still present. Closing of the casket precedes the final church or memorial service which is followed by interment. The ritual cleansing of the deceased's house and feasting completes the process, releasing the family to everyday life. While the pattern and protocols of tangi can be performed in almost any setting, they are considered to be at their most poignant and spiritual when enacted against a backdrop of ancestral and tribal symbolism (Walker, 1992).

\section{Hui - Maori Decision-Making}

Immediately following death, the whanau must make two critical decisions that will influence the mobilization of community networks and resources as well as tangi proceedings. The whanau must decide on when and whether they will cremate or bury the deceased, and they must decide where the deceased will lie in state. Options for the latter include their home, the marae or other places like churches, schools, sportsclubs or at a funeral home. With kinsfolk, friends, colleagues and related others preparing to share in the burden of grief, knowing where and when the tangi will be held is critical to their arrangements.

Maori decision-making styles are complex and often a mystery for many outsiders, who can be baffled at how and why Maori arrive at the decisions they do (Ritchie, 1992). Irrespective of imposed democratic governance structures, elected leadership and legislated procedures (eg., Boldt, Long, \& Little Bear, 1985; Deloria \& Lytle, 1998; Nettheim, Craig, \& Meyers, 2002; Williams, 1999), at the level of whanau, when death occurs, the only regulatory requirements in Aotearoa/New Zealand are: that a medical doctor signs a death certificate; that sudden deaths are investigated; and that the mortal remains of a person are disposed of in designated 
places like a cemetery or a crematorium. With these three requirements in mind whanau decision-making can proceed largely without external intrusion.

Durie $(1997,2001)$ and Metge (1995) describe the culturally prescribed roles and responsibilities of different whanau members. As the Maori world is largely though not exclusively patriarchal (Mahuika, 1992), men, particularly the first born (mataamua), carry a responsibility of leadership and whanau representation. This is modified by the requirement to receive advice from whanau members and to serve their needs and best interests. Those latter born members of whanau (who are teina to the mataamua) have a responsibility to support the decisions of their elder sibling (tuakana) and to ensure that they are all genuinely representing the whanau's plans rather than their own personal interests. While this is the general pattern, first born women and sometimes younger whanau members also fill leadership roles particularly if the tuakana abandon or cannot meet their responsibility or if teina demonstrate outstanding competence. The youngest born (potiki) of a whanau occupies a unique position, one where they are expected to ask the difficult questions, suggest other options, and push the boundaries. The reason for this is that potiki do not normally carry the weight of critical responsibilities, decisions having been made for them by their older siblings. The world that the youngest sibling is born into is often very different to that of their parents and many of their older siblings. The whanau have become more financially comfortable, and the potiki thus better educated. For these reasons, the conduct of potiki, while treated with some frustration, is understood and endured.

As the whanau group extends and new generations are born, this same system of tukana/teina and mataamua/potiki continues to structure relationships. The whanau of 
the first born are called to represent and serve the broader kinship network. And so the system is expanded with genealogy informing relatedness and positions of seniority. In the marae context, when groups of extended whanau gather, everyone has a place, a duty and a responsibility. As Maori society is ambilineal (Sinclair, 2001) descendants can rightfully claim membership in those whanau of both their parents, adding confusing and sometimes exciting complexity.

Hui means to gather, and Maori gather for many purposes (Salmond, 1976). One is to "...consider issues and make decisions about matters affecting whanau members" (Love, 2000, p.20). As Love (2000) elaborates, hui gather together people who matter, who can provide information and resources, who can show leadership and a pathway forward, and who can support outcomes. Through the process of hui, participants seek inclusion, respectful listening, the expression of views and reaching consensual outcomes. Silence is preferred to unnecessary filling of airspace but should not be read as consent. If a consensus is not reached, then whanau members are likely to defer to the leadership and seniority exercised by the elder members (both tuakana and mataamua). If dissent continues, people may withdraw their engagement to protest or avoid conflict. Hui can include a spiritual dimension, in which prayers invoke the presence of ancestors to guide and witness the search for unity within the complexity of status, history, kinship, whanau roles and the very human need for affirmation, esteem and recognition. This is referred to as kotahitanga, loosely translated as "unity', the "Holy Grail of Maoridom" (Ritchie, 1992, p.74), always sought after, but rarely found. When it is, it is treated as a precious gift. 
When bereavements occur, whanau are confronted by a labyrinth of critical and expensive decisions that need to be made within the first 24 hours following death. They must come together, to hui, to make decisions about what will happen next. If the deceased person made their final wishes known, the decision-making process is much easier. However, even in the $21^{\text {st }}$ century, some Maori still consider talking of death as tempting fate (Bern-Klug, 2004), as "karanga aitua", or calling death down. For others, it may even be seen as depriving the living of the opportunity to pay honour through a process of claiming the corpse and determining its final resting place (for example, Elliott, 2009). Indeed, it is not uncommon to hear of close kin uplifting the deceased's body from the possession of one group, at times spouses or in-laws, for removal to another location. Because of this, the party in possession is ever vigilant of such a possibility.

There is much to interest the researcher of Maori death rites, bereavement and ways of mourning. In this paper we confine our attention to the hui or decisionmaking processes undertaken by one whanau when a death occurred. We consider the period immediately following death when the whanau is called to gather, through until a clear plan emerges of where the whanau will hold the tangi and eventually bury their mother. Here the whanau experience is narrated by Rose $^{1}$, the daughter of Rangimarie and presents an opportunity to explore: whanau leadership and decisionmaking; the contribution of collective knowledge; the meaning of and connection to home; and the notion of afterlife togetherness.

\footnotetext{
${ }^{1}$ Pseudonyms have been used for all names, places and other identifying information presented in this paper.
} 


\section{The research process}

Rose is an academic colleague. She knew about our research and was always interested in what our research challenges were. After her mother died early in 2011, she approached us tell us her story. We had promised to meet, but inevitably one of us had to attend yet another tangi! In the last year, Rose has mourned the passing of three of her whanau: her biological mother, her aunt who was like a mother and more recently, her father, four months previous to us finally meeting. We considered this passage of time adequate for Rose to be able to reflect with some distance on the passing of her whanau and still retain some memory of the detail. Also, these deaths were no longer an overwhelming and consuming part of her daily life. She had dealt with her father's estate and had returned to work a month after his passing. We all knew that the act of engaging in conversation would invoke sad, moving and at times tearful remembering but treated this as another mode of human expression, much like laughing, both of which were significant aspects of our meetings (Buckle, Dwyer, \& Jackson, 2010). In saying this, we remain acutely aware that bereavement does hurt and that the bereaved are often highly vulnerable (Stroebe, Stroebe, \& Schut, 2003).

Our initial intention was to focus on the passing of Rose's mother, and then move on to her aunt, and finally her father. Our conversations were loosely structured around significant events: the process of dying; the passing; notifying whanau; decisions Rose made; decisions she left to the whanau; and progressed up until the point where an overall plan had been agreed to with respect to where Rose's mother, Rangimarie would be mourned and buried.

After the first interview, it became clear that Rose's whanau was much more complex than first anticipated. Four interviews later, our research conversations with 
Rose had only surveyed the first 24 hours following the death of Rangimarie. Yet this 'brief' period had given rise to hours of thinking, reflecting, reading and conversing with her, a process that allowed for deeper layers of meaning to emerge over the course of our discussions (Willig, 2008). At this point, we decided to pause and treat the material gathered as the primary source for the case we present in this paper.

The first and second authors took responsibility for engaging Rose in conversation, of writing up summary reports and signalling the need for elaboration or more information. The third author reviewed the summary reports and challenged the assumptions and areas overlooked by the other authors ever wary of bias and the taken-for-granted. The summary reports circulated between the researchers and Rose, with more detail, questions and a deepening appreciation of the case emerging through each cycle. Gradually, a rich picture of how and why decisions were made became apparent allowing us to move abductively (Thomas, 2010) between the literature, our own cultural experiences and Rose's narrative. From this position, we began to think critically, and to theorize about the case. Even at this time, Rose remained involved, commenting on our observations, assumptions, descriptions and conclusions. In this way, we collaboratively went about selecting information and expanding our conceptual understanding (Small, 2009) of Maori decision-making.

In the sections below, we elaborate the contextual information related to Rose's whanau and how Rangimarie came to die where she did. As the case evolves, the reader will see how Rose emerges as a critical facilitator of whanau decisions; this despite occupying the role of potiki (the last born child). How siblings discuss matters is contrasted with the more formal process of hui. Critical to decision-making is 
knowledge of history, relationships, kinship and trust that the hui process will realize the right outcome.

\section{Rose's whanau}

Rose's father Harry grew up in his tribal homeland situated at Ahipara, in the remote far north of the North Island of New Zealand. Rangimarie grew up in her tribal homeland situated in the Bay of Plenty, in the central North Island. When they married, Harry went to live with Rose because of work opportunities in her area. And Harry's siblings followed after him migrating from Ahipara to find work and to live with them for various periods of time. Members of each respective whanau grew close together and romances blossomed with siblings from one family marrying siblings from the other. The children of these unions were involved in each other's lives and many were raised by their aunties or uncles who in turn were considered by such children as their mothers or fathers.

Rose comes from a large extended whanau. Her father was the third eldest of nine siblings; but as the first born son was raised as the mataamua. At the time of Rangimarie's passing, only Harry and two of his younger siblings remained. Of her mother, Rangimarie had five siblings of which only one remains. All of Rose's uncles and aunties passed in her life time, the first in the 1980's. Rose knew her paternal grandparents but her maternal grandparents had died before she was born. Rose's partner Simon experienced the sudden lost a parent when his father had a severe heart attack in September 2006. 
Although she has two nieces also raised by Harry and Rangimarie, Rose is the last born, the potiki in her whanau. As the whanau grew, Rose's siblings left home and settled away from the large metropolitan city of Auckland where Harry and Rangimarie had raised them. Eventually, only her parents and Rose remained at their Auckland home. Rose often went with her parents to family functions and to tangi. When members of her father's family died, their family group would pack up and drive north to Ahipara and to their marae to share the burden of that death. The same was true of deaths in her mother's whanau. But not all who passed returned to their tribal homelands.

When Harry's brother Lou died in Wellington at the southernmost end of the North Island, Harry went to seek the return of their brother to Ahipara, to bury him amongst his own whanau and ancestors. They understood that they would be all buried together, at home in Ahipara. However, Lou's widow and children thought differently. They argued to retain and bury Lou in Wellington, close to where his children intended to live and raise their own. For similar reasons, Harry's sister Tere was also buried away from their homelands. She had cancer. Tere's daughter Hine was raised with Rose, but cared for her birth mother through her illness and end-oflife period. In acknowledgement of this relationship, Harry's whanau looked to Hine for advice when making Tere's final arrangements.

Each time a member of Harry or Rangimarie's whanau died, Rose and her parents and available siblings felt a strong compulsion to attend the mourning rituals and to be seen. Tangi are about the living coming to pay their respects to the deceased and especially to share their grief with the bereaved, who are present, there, by the deceased. If the bereaved whanau are not present, it is considered rude and negligent, 
and certainly curious. In her lifetime, Rose has attended many tangi not just of her extended whanau but of other more distant relatives to share in their grief. This is how Rose, like most Maori, came to know and understand tangi practices in the Maori world.

\section{Rangimarie's passing}

Rangimarie had just come out of hospital. A heart valve operated on 10 years earlier had been causing serious problems. She was at home with her husband Harry, resting and sleeping in their small two bed room flat. They had recently left Auckland where she and Harry had spent most of their lives working and raising their eight children. Auckland felt "too fast" and they found themselves disconnected from their whanau and increasingly lonely, fragile and elderly. At that time, Rose gave birth to her first child Toki, and with the passing of Simon's father months after giving birth Rose was adamant that her child grow up knowing his grandparents. Rose encouraged them to take part in Toki's life through frequent visits. When Rose's daughter was born, her parents moved to Hamilton to enjoy and care for their grandchildren while Rose and Simon worked.

Rose was at home baking and preparing a meal to share later in the day with her parents. About 3pm her father called. Her mother, asleep in her bed, had not moved for over two hours. He was concerned. Rose left what she was doing and went to their flat. On arrival, she took one look at her mother and called an ambulance. Only then did she physically examine her. Rangimarie's body was cool to the touch. Rose knew she had died and was shocked. The hospital staff had not given any indication that Rangimarie's life was so tenuous. 
The ambulance staff arrived. Unable to help, they told her they had contacted the police as the circumstances of Rangimarie's passing they deemed to be sudden. The police arrived to gather information and Rose directed them to Rangimarie's General Practitioner who provided a death certificate. Rangimarie had a chronic condition which, unbeknown to Rose, was life threatening.

Having dealt with the ambulance staff and police, and still consoling her father who was a "mess", Rose rang her husband Simon to ask him to take care of their children. She also asked him to begin contacting her siblings to let them know of their mother's passing while she began calling her uncles and aunts. She did not consciously have a 'plan' for her mother's passing, but her whanau had certain understandings about who would be first contacted when someone died.

Rose first called her mother's sister Heeni in Kereru. She broke the news by simply saying "Mum's gone" and promptly broke into tears. Rose remembers her aunt consoling her “...don't worry ...bring her home to Kereru” to their marae. This call to Heeni was to become critical to later decisions the whanau were to make. Rose then rang two uncles, both ministers of the church. They would alert other whanau members to prepare for the tangi. These uncles arrived early the next morning. Meanwhile Simon was not having much success contacting Rose's siblings, so she began to phone them. With each call, her telling of Rangimarie's passing became more descriptive, her critical message being "Mum's gone. Dad needs you. Come". And so her whanau began the familiar process of coming together to share in their grief and to undertake decisions about what would come next.

\section{A whanau gathers}


Sometime before $6 \mathrm{pm}$, Simon arrived with their children. Until then, Rose and her father had been alone together with Rangimarie. Periodically, Harry would ask whether Rose had contacted certain people but otherwise, stayed beside Rangimarie savouring what he knew would be his last few private moments before having to share her with others.

Rose's niece and boyfriend were the first to arrive from Auckland (a two hour drive). Next was her brother from Nelson in the South Island. When he heard of his mother's passing, his wife immediately booked him on the first two hour flight out of Nelson. Then, her brother, his wife and two daughters from Helensville arrived (a two hour drive), and then Rose's sister, husband and niece from Taranaki (a four hour drive). During these arrivals, Harry sat with Rangimarie, in their bedroom and greeted his whanau. Rose also phoned her oldest brother from Kaitaia. When first contacted, he was inebriated and unable to drive. She had called him about 4-5 times until it became apparent that he was in no state to travel. She urged him to sleep it off and come the next day as it was important that he be a part of the conversation about where they were to take their mother.

\section{The search for final wishes}

About midnight, after the whanau had settled in, talk amongst siblings turned to final arrangements. "Has Dad said what he wants for Mum?" "Did Mum say what she wanted?" Rangimarie had been firmly of the belief that talk of one's own death and final arrangements tempted fate and called death into being. Even so, Rose and her siblings had had passing conversations with Rangimarie; nothing definitive but enough to make them take note. That night, they shared what they knew. 
Three possibilities emerged. One was to bury her at Waikumete public cemetery in Auckland where Rangimarie and Harry had lived and raised their children. That was quickly discarded as all of the whanau had moved away from the area. They felt that in Waikumete cemetery, Rangimarie would lie alone. Another possibility was to return Rangimarie to Kereru where she had grown up within her tribal homelands. The last possibility was to take her to Ahipara, to Harry's tribal homeland and bury her there. Rose and her siblings present that night resolved to leave the final decision to Harry provided his decision made good sense to them. Eventually, the greatly increased household retired to a very restless night in the small flat with their beloved mother lying in her bed where she had died.

\section{A whanau hui}

Just before 6am, Rose received a text message letting her know that a car load of family from Kereru was due to arrive. The group comprised of two ministers (Harry's brother Natana and Rangimarie's nephew Hotu) and two of Rangimarie's neices Marata and Ruth. About this time, Rose had also spoken with her older brother and knew that he was only just beginning his journey from the North. He was going to miss the hui.

When the Kereru relatives arrived, they began karakia or prayers with the whanau gathered in Rangimarie's room where she still lay. There was no mention of any plans or of what would come next until karakia had concluded. Hotu then opened up a conversation about where they were to take Rangimarie. Rose took the lead telling of the talks that occured the previous night with her siblings and of the three possibilities they had identified based on what they knew of Rangimarie's final 
wishes. She told them that they had ruled out Waikumete cemetery as they did not want their mother to lie alone in a strange place. She reported that taking Rangimarie to Ahipara or to Kereru were the only realistic options but that they would support whatever decision Harry made. After Rose concluded, her father took up the conversation. This is Rose's account of what he said:

He explained that he would have liked Mum to have gone to Ahipara but he didn't feel right to take her up there. He said that if he had gone first and Mum followed, then no problem. He knew in his heart that she didn't really want to go to Ahipara. If she did, then they would have been there already because Dad had been nagging her for twenty odd years. So, he said that it felt more right for her to go to Kereru.

Her father asked Rose and her siblings how Kereru had arisen as an option. Rose explained that she had had a conversation with her mother one day as they were walking around the cemetery at Kowhai, visiting Rangimarie's parents and sisters who were buried there. Rangimarie had quietly said to Rose "I want to come back here". That was all she had said. Rose read this to mean that her mother wanted to return to Kereru, to be buried in the cemetery called Kowhai.

Hotu then entered the conversation. He had earlier been in contact with Rangimarie's half-sister Heeni, the aunt who Rose had phoned first. Hotu reinforced Heeni's earlier call for Rose to bring her mother home indicating that there was plenty of space in the new cemetery near the marae at Kereru. It was common knowledge that the Kowhai cemetery had been closed to all except those of a specific whanau lineage, regardless of who had been buried there previously. Rangimarie's parents and siblings were buried there, but this was not a strong enough claim to realise 
Rangimarie's final wishes. Customary process required that they receive an invitation from a recognised member of that cemetery's specific whanau lineage, to deflect the challenge and envy of others. Although Heeni had told Rose to bring her mother home, she had not said to which cemetery. She had not offered an invitation for Rangimarie to be buried at Kowhai.

\section{Home to where?}

In the absence of a clear invitation, the conversation turned to what people meant by taking Rangimarie "home". There was the option of burying Rangimarie in the new cemetery, which Hotu advocated, but Rangimarie would be the first of their family to be buried there and would lie alone until the next family member died. It also assumed that Rose and her siblings had a desire to also be buried at Kereru in the new cemetery. If Rangimarie was buried at Kowhai, she would lie in the embrace of her parents and siblings but not her own children.

These arising issues spawned a discussion surveying where Rose and her siblings intended to be buried. As talk progressed, it became apparent that only Rose and her sister had any intention of returning to Kereru, their siblings choosing to be buried where they were living, to be cremated, or their remains donated to science. Rose said that if she could not be buried with her mother, then she wanted to be “...cooked and her ashes buried with Mum”. Wishing the same outcome for himself, Harry announced that he too wanted to be cremated and buried with Rangimarie.

\section{A resolution is found}

At some point in the coversation, Hotu had left the room to make a phone call to Heeni, the first person Rose had called. While Heeni and Rangimarie share the same mother, it is Heeni's father who is from the whanau who consider themselves to be 
the rightful inheritors of the Kowhai cemetery. Heeni is considered knowledgeable in land matters, history, genealogy and active in tribal governance. She is always present at tribal meetings and events in the community. If anyone was able to wield any authority with respect to the dilemma Rose and Harry found themselves in, it was Heeni. Eventually, Hotu returned to the room and made the content of his conversation known. Heeni had said that there was a space in the Kowhai cemetery at the feet of Rangimarie's parents where she could be buried. If the grave was deepened then space could be made for Harry as well. Both were welcome.

So a resolution was found. A decision was made even though Rose's elder brother's participation was vicarious through telephone calls. A sense of kotahitanga, of unity, relatedness and belonging, to this world and the next prevailed. The pursuit of customary process reassured the people involved that the right actions had been followed for themselves, their mother, sister and wife.

Up until this time, the broader extended whanau were waiting on the outcome of these discussions. They stayed away from what they saw as intimate whanau business that needed resolving. It was pointless doing anything until people knew where Rangimarie was to be buried. Now that a pathway forward was established, the broader extended whanau and communities of interest could set in motion the next phase of preparing the marae at Kereru to receive and mourn for Rangimarie.

\section{Discussion}

This case study considered the period immediately following the death of a mother and the decision-making processes engaged in by her spouse and whanau, to 
determine a clear plan concerning where they would hold her tangi and eventually inter her. How did this whanau know what to do? What does this case tell us about whanau leadership and decision-making by Maori confronted by death in this modern world? How do collective moments and knowledge of the deceased's final wishes contribute to their realisation? What is the meaning of home, and how do Maori continue to pursue a sense of identity and connectedness with ancestral places? How does the burial of the dead, together, relate to togetherness in the afterlife? We discuss these questions below.

\section{Responding to death}

Maori are a fourth-world people (Moody, 1993). They live their lives in the presence of other New Zealanders, many away from their tribal homelands in urban areas where work, education, healthcare and other services are easily accessible (Nikora, 2007). Tangi present an opportunity for Maori to leave their everyday lives to fully participate in the cultural milieu of the Maori world where kinship reinforces relationships, decision-making and collective activities, and where custom informs the rightness of representations, rituals and engagements. In framing events in this way, the episodic nature of the Maori world takes form (Salmond, 1976). While in continuous existence, it is one that causes its members to gather when confronted by crises, moved by love or excited by achievement. Although the whanau unit is a critical agent of enculturation, one only really comes to live and know the reality of the Maori world by participating in it. Rose and her whanau were no strangers to the institution of tangi. They grew up participating in such events in varying capacities and as prescribed by kinship relatedness. When Rangimarie passed, they knew what needed to be done and had, in tangi, a cultural template to guide them. 


\section{Whanau leadership and decision-making}

Rose sits between her parent's and children's generations (Zal, 2001). As members of her parent's generation physically or socially die, the leadership and decision-making responsibilities gradually pass to Rose's generation but not before proceeding through the remaining siblings of her parents. In this case, we can see parents and children working together to make decisions for their own immediate whanau to realize the aspirations of the bereaved. The wider whanau offers support.

Rose is the potiki in her whanau, the last born. Traditionally, the last born did not usually demonstrate such influence in whanau decision-making, however, the situation was different for Rose. She was knowledgeable and experienced in ways and relationships different to those of her siblings due perhaps to her being the last of her siblings to leave home. She carried the burden of care for her mother and father, and in return, and possibly because of her university level education, they privileged her with insight into their needs and desires including their financial affairs, and relationships with those of their own generation. This is recognized by Rose's own siblings, her father, her aunts and uncles. They permit Rose space to articulate both her personal views and those of her siblings because she has achieved a status beyond that of her ascribed status as the last born. If Rose was acting outside of what was culturally expected, she would have been at best, firmly reprimanded, at worst, ignored.

\section{Contributing collective knowledge}

The case study describes how Rose and her siblings were enculturated into the Maori world and its customs, as children, as members of an extended whanau, and as 
participants at tangi. Their mother held closely to the practice of karanga aitua - of not tempting fate by openly expressing her desire to be buried with her own mother. Through reviewing their individual experiences with Rangimarie, her children and husband were able to confidently ascertain what she wanted in a way that concurred with their combined observations, even though it required the input of people from their extended whanau to realise her wishes.

Kotahitanga refers to the search for unity within the complexity of status, history, kinship, and the human need for affirmation, esteem, and recognition. Kotahitanga might be loosely translated as 'unity', described by Ritchie as the "Holy Grail of Maoridom - rarely found" (Ritchie, 1992). For Harry and his children, in collaboration with their extended whanau, kotahitanga was achieved.

\section{Home and afterlife unity}

Since the early 1900's, Maori have experienced waves of migration away from their tribal homelands for work, education, housing and improved lifestyles ( $c f$. Nikora, Guerin, Rua, \& Te Awekotuku, 2004). Traditionally, the dead would be returned to their tribal homeland, mourned, honoured and buried (Buck, 1962). To be buried elsewhere was considered negligent on the part of the deceased's broader extended whanau, as their tribal community hold them responsible for ensuring the continuity of whanau, living and dead, with their tribal homelands. It is considered even more offensive if the spouse and in-laws, against the wishes of the deceased's blood kinfolk, defiantly assert their possession of the deceased for tangi and interment. Dispute and lamentation can and does continue for decades. For these reasons, most Maori actively seek the return of their deceased kin to be interred with 
other members of the whanau and tribe. In this case, the initial telephone call by Rose to Rangimarie's half-sister Heeni, opened the way for Heeni to claim Rangimarie's body which she did by instructing Rose to bring Rangimarie home. While Heeni did not join the whanau hui, she had her delegate in Hotu, the mediator of information between Rose's whanau and Heeni. Between them they were able to resolve for Rangimarie and her whanau their desire for continuity with ancestors and those living in their tribal homelands. In this instance, home is both a place of genealogical and lived connectedness with those committed to an entwined future and past. The death of Rangimarie tested the strength of this commitment and presented for Heeni and Hotu the opportunity for its reaffirmation.

Against this context, home is traditionally a place within one's tribal homeland, with closely related kin, together in life and death. The experience of Rose's whanau is not unique and it reflects a continuing desire and expectation to return home to be buried amongst one's ancestors. However, what is unusual, is Harry's desire to be buried with Rangimarie in her tribal area rather than returning to the North, to his own place and people. The choices expressed by some of Harry's children to be buried in urban areas, to be cremated, or to donate their remains to science have not commonly been pursued, but are becoming more popular. They present a different way for Maori living beyond their tribal homelands to remain more closely together in life and death. These choices may provide different conceptions of what defines "home", as a significant and spiritual place for future generations.

\section{Conclusion}


The journey of loss, decision making, and location by Rose and her whanau on their mother Rangimarie's death describes their collective experience of coping and coming together, achieving kotahitanga, to honour their mother's passing.

This account considers the relationships of family members to each other, to their places of ancestral and immediate meaning, and to their mourning with each other. Through conversations and whanau hui, particular fears were confronted or discussed, memories were reviewed, and a clear direction was ascertained and acted upon. The wider community of extended whanau and hapu were duly involved, offering affection, physical support, advice and customary ritual. Of particular note was the burial place, and related discussions. Death in the Maori world is rarely a matter of being alone, unidentified, or neglected; it is the tearful concern of whanau, it becomes the business of the wider community; and ironically, the loss of one person often causes the addition of others to a community, to a place. They return to mourn; they stay. In her passing, Rangimarie returned to her community; her husband and children will visit her there, her name will continue to be honoured, and her descendants recognised. In some distant future, members of this whanau will know where to go for each other, and what to do. 


\section{References}

Barlow, C. (1991). Tikanga Whakaaro = Key Concepts in Maori Culture. Auckland, NZ; New York: Oxford University Press.

Beaglehole, E., \& Beaglehole, P. (1945). Contemporary Maori Death Customs. Journal of the Polynesian Society, 54, 91-116.

Beaglehole, E., \& Beaglehole, P. (1946). Some Modern Maoris. Wellington, NZ: New Zealand council for Educational Research.

Bern-Klug, M. (2004). The Decision Labyrinth: Helping Families Find Their Way through Funeral Options. Generations, 28(2), 31-36.

Best, E. (1914). Cremation Amongst the Maori Tribes of New Zealand. Man, $14,110-112$.

Boldt, M., Long, J. A., \& Little Bear, L. (1985). The Quest for Justice : Aboriginal Peoples and Aboriginal Rights. Toronto; Buffalo: University of Toronto Press.

Buck, P. (1962). The Coming of the Maori. Wellington, NZ: Whitcombe \& Tombes Ltd. 
Buckle, J. L., Dwyer, S. C., \& Jackson, M. (2010). Qualitative Bereavement Research: Incongruity between the Perspectives of Participants and Research Ethics Boards. International Journal of Social Research Methodology, 13(2), 111-125.

Dansey, H. D. B. (1992). A View of Death. In M. King (Ed.), Te Ao Hurihuri: Aspects of Maoritanga (pp. 105-116). Auckland, NZ: Reed Publishing Limited.

Deloria, V., \& Lytle, C. M. (1998). The Nations Within: The Past and Future of American Indian Sovereignty. Austin, Texas: University of Texas Press.

Durie, M. (1997). Whanau, Whanaungatanga and Healthy Maori Development. In P. Te Whaiti, M. McCarthy \& A. Durie (Eds.), Mai I Rangiatea: Maori Wellbeing and Development. Auckland, NZ: Auckland University Press.

Durie, M. (2001). Mauri Ora : The Dynamics of Maori Health. Melbourne ; Oxford: Oxford University Press.

Edwards, S., McCreanor, T., Ormsby, M., Tuwhangai, N., \& Tipene-Leach, D. (2009). Maori Men and the Grief of Sids. Death Studies, 33(2), 130-152.

Elliott, M. (2009). Billy T: The Life and Times of Billy T James. Auckland, NZ: HarperCollins.

Harawira, W. (1997). Te Kawa O Te Marae: A Guide for All Marae Visitors. Auckland, NZ: Reed.

Hera, J. (1996). Reclaiming the Last Rites (Rights): Women and after Death Policy, Practices and Beliefs in Aotearoa New Zealand. Unpublished PhD Thesis, Palmerston North, NZ: Massey University. 
Jacobs, J., Nikora, L. W., \& Ritchie, J. (2011 in press). Maori Children and Death: Views from Parents. Australia Community Psychologist.

Love, C. (2000). Family Group Conferencing : Cultural Origins, Sharing and Appropriation - a Maori Reflection. In G. Burford \& J. Hudson (Eds.), Family Group Conferencing : New Directions in Community-Centered Child and Family Practice (pp. 15-30). New York: Aldine de Gruyter.

Mahuika, A. (1992). Leadership: Inherited and Achieved. In M. King (Ed.), Te Ao Hurihuri (pp. 43-64). Auckland, NZ: Reed.

Matenga-Kohu, J., \& Roberts, J. (2006). Tangihanga Māori Burial Rituals. Cambridge, NZ: Wotz Wot Ltd.

Mead, S. M. (2003). Tikanga Māori: Living by Māori Values. Wellington, NZ: Huia Publishers.

Metge, J. (1976). The Maoris of New Zealand : Rautahi. London, UK; Boston, MA: Routledge \& K. Paul.

Metge, J. (1995). New Growth from Old : The Whanau in the Modern World. Wellington, NZ: Victoria University Press.

Moody, R. (1993). The indigenous voice : visions and realities (Rev., 2nd ed.). Utrecht, Netherlands: International Books.

Nettheim, G., Craig, D., \& Meyers, G. D. (2002). Indigenous peoples and governance structures : a comparative analysis of land and resource management rights. Canberra, AUS: Aboriginal Studies Press, Australian Institute of Aboriginal and Torres Strait Islander Studies 
Nikora, L. W. (2007). Maori Social Identities in Hawai'i and New Zealand. PhD, University of Waikato, Hamilton, NZ.

Nikora, L. W., Guerin, B., Rua, M., \& Te Awekotuku, N. (2004). Moving away from home: Some social consequences for Tuhoe migrating to the Waikato. New Zealand Population Review, 30(1\&2), 95-112.

Nikora, L. W., Te Awekotuku, N., Rua, M. R., Temara, P., Maxwell, T., Murphy, E., et al. (2010). Tangihanga - the Ultimate Form of Maori Cultural Expression. In J. S. Te Rito \& S. M. Healy (Eds.), Proceedings of the 4th International Traditional Knowledge Conference 2010. Kei muri i te kapara he tangata ke - Recognising, Engaging, Understanding Difference (pp. 400-405). Auckland, NZ: Ngā Pae o te Māramatanga/New Zealand's Māori Centre of Research Excellence.

Ritchie, J. E. (1992). Becoming Bicultural. Thorndon, Wellington, NZ: Huia Publishers : Daphne Brasell Associates.

Salmond, A. (1976). Hui: A Study of Maori Ceremonial Gathering. Auckland, NZ: Reed Methuen.

Sinclair, K. (2001). Mischief on the Margins : Gender, Primogeniture, and Cognatic Descent among the Maori. In L. Stone (Ed.), New Directions in Anthropological Kinship (pp. 156-174). Lanham, Maryland: Rowman \& Littlefield Publishers.

Small, M. L. (2009). 'How Many Cases Do I Need?' : On Science and the Logic of Case Selection in Field-Based Research. Ethnography, 10(1), 5-38. 
Stroebe, M., Stroebe, W., \& Schut, H. (2003). Bereavement Research: Methodological Issues and Ethical Concerns. Palliative Medicine, 17(3), 235-240.

Taipari, G. (2010, April 6). Cremation Gaining in Popularity - Even with Maori. The Daily Post. Retrieved from http://www.rotoruadailypost.co.nz/

Tauroa, H., \& Tauroa, P. (1986). Te Marae : A Guide to Customs \& Protocol. Auckland, NZ: Reed Methuen.

Te Awekotuku, N., Nikora, L. W., Rua, M. R., \& Karapu, R. (2007). Mau Moko: The World of Maori Tattoo. Auckland, NZ / Honolulu: Penguin / Hawai'i University Press.

Thomas, G. (2010). Doing Case Study: Abduction Not Induction, Phronesis Not Theory. Qualitative Inquiry, 16(7), 575-582.

Tomas, N. (2008). 'Ownership of Tupapaku'. New Zealand Law Journal, July, 233-236.

Walker, R. (1992). Marae : A Place to Stand. In M. King (Ed.), Te Ao Hurihuri: Aspects of Maoritanga (pp. 21-30). Auckland, NZ: Reed.

Williams, D. V. (1999). 'Te Kooti Tango Whenua' - the Native Land Court 1864-1909. Wellington, NZ: Huia Publishers.

Willig, C. (2008). Introducing Qualitative Research in Psychology : Adventures in Theory and Method. Maidenhead, Philadephia: McGraw-Hill Open University Press. 
Zal, H. M. (2001). The Sandwich Generation: Caught Between Growing Children and Aging Parents. Cambridge, Massachusetts: Da Capo Press. 